Article

\title{
The Food Desert as a Concept and Policy Tool in African Cities: An Opportunity and a Risk
}

\author{
Jane Battersby
}

African Centre for Cities, University of Cape Town, Private Bag x3, Rondebosch 7701, South Africa; Jane.battersby.lennard@gmail.com

Received: 9 November 2018; Accepted: 9 January 2019; Published: 16 January 2019

check for updates

\begin{abstract}
The idea that food insecurity can be resolved by increasing the presence of supermarkets has been gaining traction in African cities and has recently gained political traction in Africa. This paper interrogates the potential value and risks associated with the adoption of the discourse of the food desert in the African context. The paper draws on findings from a households survey, neighborhoods-scale food retail mapping and surveys, and city-wide supermarket mapping conducted in Cape Town (South Africa), Kisumu (Kenya), and Kitwe (Zambia). Following a discussion of why the concept is gaining traction, the paper identifies false assumptions associated with the food desert framing in Africa, namely: supermarkets provide better access to healthier food, low-income areas have poor access to healthy food; and food security can be reduced to economic and physical accessibility. The paper concludes that although the food desert concept may be valuable for African researchers to provoke debates about systemic inequality, the food desert policy narrative should be rejected as it is ill-informed by the lived experiences of food insecurity in African cities and may promote policy interventions that erode rather than enhance the capacity of the food system to meet the food security needs of African urbanites.
\end{abstract}

Keywords: food desert; food security; food justice; African urbanism; African food systems; food policy

\section{Introduction}

Having gained significant political traction in the United States, United Kingdom, and elsewhere in the global North, the idea that food insecurity can be resolved by addressing food deserts through increasing the presence of supermarkets has been gaining traction in African cities. Government support of supermarket expansion has been implicitly and explicitly articulated by urban policy makers in public statements, planning decisions and official documents.

In Kenya, for example, the national government's Vision 2030 document released in 2007 stated the intention to increase the market share of products sold through "formal channels (e.g., supermarkets) from the current $5 \%$ to $30 \%$ by 2012" in an effort to "move towards greater efficiency in the country's marketing system" [1] (p. 13). In Zambia, the growth of Shoprite has been attributed, at least in part, to tax rebates and import tariff concessions [2]. Local governments articulate supermarkets and shopping malls as not only having the potential to "provide the council with more revenues but also beautify the city" [3] (p. 136). This articulation by policy-makers has been informed, in part, by influential academics who have argued that supermarkets have the potential to improve food security in developing countries [4].

The language of the food desert itself is a recent addition to the policy lexicon and has layered a food security framing on top of this existing predilection towards supermarkets. The most explicit articulation is found in the City of Cape Town's Resilient Cape Town: Preliminary Resilience Assessment [5], which reflects on the findings of Cape Town's reporting against the Rockefeller 
Foundation's 100 Resilient Cities indicators. This document asks "Where are the food deserts in the city? How can we improve access to affordable and nutritious food?" [5] (p. 75). The invocation of a food desert framing marks a shift in political discourse about urban food insecurity in Africa.

The purpose of this paper is to interrogate why the language of the food desert is gaining political momentum in the African context and what the potential impact of food desert-led policy framings on food security may be. Additionally, it reflects on whether the food desert as an analytical tool has value in the African context. Central to this discussion is the definitional politics of food deserts, and how varying definitions reflect different political framings of food insecurity and trigger divergent types of solutions.

The paper first grounds itself in a discussion of the ways in which food insecurity has historically been framed and engaged in the African context. This discussion is used to explain why the supermarketization-as-pathway-to-food-security notion has begun to gain political traction. Following this, the paper then critically engages the linkages between the concept of the food desert and its mobilization as a policy tool.

Having situated the concept of the food desert and its mobilization in literature and policy debates, the paper then engages with three weaknesses of the food desert concept as currently articulated with African cities, namely: supermarkets provide better access to healthier food; low-income areas have poor access to healthy food; and, food security can be reduced to economic and physical accessibility in narrow terms. These assumptions are challenged by findings from research in Cape Town (South Africa), Kisumu (Kenya), and Kitwe (Zambia), three of the countries in Africa that have been most politically open to supermarket expansion. The current market share of supermarkets in South Africa is estimated to be up to $75 \%$ of all grocery sales, with an estimated $92 \%$ of stores being from South African-owned companies [2,6]. The estimated market share of supermarkets in Kenya in 2003 was $20 \%$, and there has been considerable expansion since then, although no conclusive figures are available. The Kenyan supermarket sector is largely dominated by domestic companies [7]. In Zambia, in 2009 it was estimated that supermarkets had a 12\% market share [8], and as in Kenya, there has been significant expansion in the number of supermarkets since then. According to 2016 figures, just four of the 77 supermarkets counted in Zambia were Zambian owned, with South African stores dominating the sector [2] (p. 322).

The work seeks to address what Thow et al. [9] have identified as an under-researched area, that of consumer interaction with food supply via purchasing behavior, by consolidating food security and food systems data from two research projects explicitly designed to address the dialectic relationship between consumers and the food system in the three case study cities. The paper concludes by reflecting on how the concept of the food desert may be productively engaged by food researchers in Africa.

\section{Framings of Food Security in African Cities}

This section interrogates why the supermarket has come to be viewed as a solution to food insecurity in African cities. To do so, the section first examines how urban food security has historically been engaged in African food security policy. It follows this with a discussion about the discourses of urban development in Africa and how the supermarket embodies some of the aspirations of urban modernization.

For the purposes of this paper, the 1996 FAO (Food and Agriculture Organization of the United Nations) definition of food security is used: "the situation that exists when all people, at all times, have physical and economic access to sufficient safe and nutritious food that meets their dietary needs and food preferences for an active and healthy life" [10] (p. 169). On the basis of this definition, the paper also frames food security in terms of the four pillars proposed by the FAO: Availability; Food Access (Physical and Economic); Utilization; and Stability [11].

This definition and framing is the one most commonly used by governments in Africa and development agencies when engaging questions of food security. However, this paper 
argues that despite this adoption, policies and programmes have failed to engage all four pillars and have therefore often failed to work towards food security as defined.

Historically, and currently, global- and national-scale food security reports and policies have disproportionately framed food insecurity as a rural problem. Crush and Riley [12] provide an overview of the ways in which the FAO's annual State of Food Insecurity and State of Food and Agriculture reports have persistently neglected urban food insecurity. They further demonstrate how African Union reports and other continental publications replicate the narrative evident in the FAO documents. This rural framing persists despite the recently released initial findings of a 146-country survey by the FAO which found that $50 \%$ of urban populations in least-developed countries were food insecure, compared with $43 \%$ in rural areas [13] (p. x).

As a result of this framing, the primary targets of food security policy are rural smallholder farmers. Current approaches to food insecurity are therefore dominated by what has been termed the "twin-track approach" of "(a) direct interventions and social investments to address the immediate needs of the poor and hungry (food aid, social safety nets, and so on) and (b) development programmes to enhance the performance of the productive sectors ..., create employment and increase the value of assets held by the poor" [14] (p. 529). This approach largely ignores the principle of the four pillars on which food security is supposedly built. It highlights availability and access through direct provision.

It has been argued that this current rural bias in policy is a corrective against the historic urban bias in national policies. Indeed, much of African agricultural policy has been designed to ensure a constant flow of basic food to supply urban labor at relatively low prices [15]. The state historically controlled much of the food system through marketing boards, control of milling, regulation of market sites, and control of land use to prevent urban agriculture which would compete with food produced by commercial agriculture [16]. Governments in Africa have therefore sought to address a base level of food security through focusing on ensuring availability and economic accessibility of staples [17]. However, this rigid state control of the agricultural system has declined with the end of marketing boards and failures of local government to control market sites [3]. The sweeping liberalization of African food systems has enabled large-scale private sector actors to position themselves as partners in development [18]. This shifting role of the private sector in the food system is echoed in the urban system. Large private sector actors are increasingly creating city visions and funding new developments shaped by an economic growth agenda [19]. As a result of this, shopping malls are commonly viewed as deliverers of local economic development, employment, and as symbols of modernity [20], despite their frequent economic failures and clear mismatch with urban morphologies in many African cities [21].

As control of the food system shifts from public to private sector actors in Africa, it is unsurprising that supermarkets are viewed by city planners as effectively replacing state-managed market places as the means by which urban residents access affordable food. The rise of the language of food deserts in African cities must be understood in the context of the shifting power structures within both the food system and the urban system.

However, while support for supermarkets as a means of private delivery of a public good (i.e., affordable food) is implicit, as typified by Zambia [2], formal urban food security policy focusses almost exclusively at the household scale [22]. Municipal governments in Africa generally do not have a formal food security mandate as a result of the historical framing of food security as a rural issue, and therefore have very limited policy and programming to address the challenge. Any programs tend towards interventions at the household and individual scale, such as support for urban agriculture, direct social assistance, and nutrition education. It is clear though that the determinants of food security extend beyond the household and individual scales. From a research and policy perspective, the concept of the food desert forces a shift in scale and framing of food insecurity, from the household to the neighborhood and city scale, and from being a problem of poverty to being one of structural inequality. It is therefore of value to consider the use of the food desert concept as a way to progress 
policy framings. However, at the heart of the food desert work is a contradiction, which has been evident from its earliest application in the US context.

\section{The Food Desert as a Concept and a Policy Tool in the US}

There is a fundamental tension at the core of the food desert concept between its use as an analytical tool and a policy tool. The food desert as an analytical tool has been extremely influential in raising civic and political awareness of challenge of food insecurity in the United States. The origins of the concept of the food desert are important to note in the context of this paper's argument. The first recorded articulation of the problem of the food desert was by a resident of a Scottish public sector housing scheme in the early 1990s [23]. The fact that the concept was first articulated by civil society actors and not academics or policy-makers is important, as it perhaps explains why there is no single agreed upon definition of food deserts in the academic context, but also because it situates the identification of the problem as a community-driven, context-specific issue.

Unlike in the African context where food insecurity has generally been analyzed and responded to at the household scale, the way the food desert concept has been mobilized by academics and civil society actors privileges the community/neighborhood scale. In doing so, it has the potential to raise issues about structural inequalities in the food system and how this inequality co-exists and is compounded by other forms of structural inequality [24] through evocative maps providing undeniable evidence of inequity when poor food access data are overlaid on other spatial indicators. The early food desert work therefore highlighted issues of income poverty, race, and mobilities and other markers of structural inequality $[25,26]$. Further, it drew attention to urban planning and financing processes which drove the development of food deserts, historicizing the food desert the context of residential and retail redlining [27]. The food desert was therefore viewed as a political problem to be engaged, not a policy problem to be fixed.

Despite cautions from academia to not conflate food deserts with the absence of supermarkets mboxciteB28-sustainability-395854,B29-sustainability-395854, the adoption of a national food desert mapping project by the USDA in 2009 reinforced this simplistic framing of the issue and effectively depoliticized it. While a firm definition of food deserts had been (intentionally?) elusive to food justice researchers, the USDA provided a single definition of a food desert. A food desert, according to the USDA is "a low-income census tract where a substantial number or share of residents has low access to a supermarket or large grocery store," and "large grocery stores" are "stores with at least \$2 million in sales that contain all the major departments found in a traditional supermarket" [30]. This definition does three things. Firstly, it simplifies the relationship between consumer and food retail, ignoring people's lived geographies and foodways [31]. Secondly, it privileges large retailers over other forms of access to healthy foods, be they small retailers, farmers markets, or urban agriculture [32]. Finally, it makes the food desert a problem to be solved by large private sector actors and reduces the agency of residents. Activist scholars have equated the relationship between the state and supermarkets in food desert amelioration efforts as akin to land grabs in the global south, both driven by public subsidies and below market land prices. They have argued that the current food desert framing is ahistorical, failing to acknowledge the reasons for current retail geographies [33]. Researchers have also highlighted the way in which incentivized supermarket entrance into areas labelled as food deserts acts as a form environmental gentrification, ultimately driving multiple forms of displacement [34].

As Block et al. [35] (p. 204) have noted, "Food access inequalities highlight how the experience of living in poorer communities is hugely different from the experience of living in wealthier ones and that these differences can even lead to increased death. However, their abilities to highlight these inequalities often leads to a public response that focuses on only the food stores themselves, rather than a broader focus upon the broader inequalities in economic investment, political and economic power, and health that the food desert issue highlights." The food desert concept had its origins in a community articulation of food system injustice, the policy trajectory marks an erasure of community agency. 
The power of food desert maps as a diagnostic tool has led to a fundamental challenge for food justice activists [36]. The production of a food desert map as a technical artefact has enabled policy-makers and retailers to condense the complex dynamics of the food desert into a technical issue that can be solved by the insertion of a supermarket, a farmer's market [37,38], a new bus route [39] or some other externally-generated single solution, and effectively reduced community agency [32]. Giacalone [36] argues that the production and circulation of the maps has depoliticized the food desert and has reduced the food access problem to a technical, rather than structural and political challenge. It is within this critique of the technical solutions to a complex problem as a result of the act of mapping which is the starting point for the discussion of food deserts within the African context.

In 2016 the USDA released findings that the presence or absence of supermarkets in fact had limited access on food choice [40]. However, despite this, the rhetoric of the food desert as a problem to be solved by the establishment new supermarkets persists and is reinforced by the technopolitics of the production of food desert maps.

\section{Methods}

This paper draws on research conducted for the African Food Security Urban Network (AFSUN) in Cape Town (South Africa) and the Consuming Urban Poverty Project (CUP) in Kisumu (Kenya) and Kitwe (Zambia). These countries are particularly appropriate to interrogate the political mobilization of the notion of the supermarket as the solution to urban food insecurity, as they have been implicitly and explicitly among the most supportive of retail formalization in Africa, as explained in the introduction.

Thow et al. [9] have argued that although there are bodies of work focusing on consumers and on food supply systems in Africa, there is a critical gap on consumers' interactions with the food supply systems in operation. The AFSUN and CUP work explicitly to address this gap, and framed it in a wider set of governance questions. In both projects there were three independent research components designed to be brought together to address this gap, which are described below. This paper brings the findings from these three components together to address the question of the food desert in African cities.

The methods and sample strategies for each research component have been previously published and references are provided in text. Given the local contexts in each city, there was slight variation in sampling strategies.

The first research component was a household food security survey, which included questions on the food-sourcing strategies of households, which provide insights on the relative importance of the informal food economy and other retail sources, including supermarkets. Levels of household food insecurity were measured using the Household Food Insecurity Access Scale (HFIAS) and the Household Food Insecurity Prevalence (HFIAP) tool [41]. The survey was conducted in 1060 households in three low-income areas of Cape Town in 2008 [42], in 882 households in two low-income areas of Kitwe in 2016 [43], and 841 households in a city-wide survey in Kisumu [44].

The second component was a food retail census and survey. The purpose of this work was to generate a spatial representation of the nature and distribution of informal food retail, and then to examine retailer characteristics, locational strategy, business practices, sourcing of retail products, and problems experienced by vendors. In Cape Town this research was conducted in 2013 and mapped 492 retailers and surveyed 100 of these retailers in two of the low-income neighborhoods in which the food security surveys had been conducted [45]. The corresponding research in Kitwe and Kisumu was conducted in 2016. In Kitwe, 705 retailers were mapped in the city's central market area and the two neighborhoods in which the household surveys had been conducted. From this mapping, 389 retailers were surveyed [46]. In Kisumu, 2185 retailers were mapped in the city center, at the city's main central retail and wholesale markets, and in a low income neighborhood. From these, 705 surveys were conducted [47]. 
The final study was a mapping of supermarkets. In Kisumu and Kitwe, the mapping was restricted to currently present supermarkets. In these cities, street addresses of the retailers were mapped onto current city maps in order to identify the kinds of urban spaces that supermarkets were located in, in terms of residential characteristics, business areas, and proximity to other critical infrastructure, such as transit hubs, markets, and malls. In Cape Town, a time-series of supermarket expansion from 1994 to 2013 was conducted [20]. Detailed analysis of the 2013 supermarket location was conducted with reference to supermarket company, and income levels of neighborhoods in which stores were located [48].

\section{Core Findings}

This section presents the key findings from the three components of the AFSUN work in Cape Town and the CUP work in Kitwe and Kisumu. In many ways, these core findings accord with the other limited research on urban food issues in African cities.

The field work in the cities found high levels of food insecurity (Table 1). The Cape Town survey, working in three low-income neighborhoods found $80 \%$ of households to be moderately or severely food insecure according to the Household Food Insecurity Access Prevalence tool [42]. A follow-up city-wide survey in 2013 found about half of the sampled population, which included all income groups, found around half of households fell into these categories [49] (p. 27). In Kisumu, a city-wide survey, $71 \%$ of households were moderately or severely food insecure [44], and in Kitwe, the corresponding proportion in the two low-income areas sampled was $90 \%$ [43].

Table 1. Levels of food security in case study cities. Note: The Cape Town and Kitwe surveys were conducted in low-income neighborhoods. The Kisumu survey was a city-wide survey.

\begin{tabular}{ccccc}
\hline & Severely Food Insecure & Moderately Food Insecure & Mildly Food Insecure & Food Secure \\
\hline Cape Town & $68 \%$ & $12 \%$ & $5 \%$ & $15 \%$ \\
\hline Kitwe & $79 \%$ & $12 \%$ & $3 \%$ & $6 \%$ \\
\hline Kisumu & $45 \%$ & $26 \%$ & $9 \%$ & $20 \%$ \\
\hline
\end{tabular}

This food insecurity was characterized by limited dietary diversity and distinct hungry seasons. These findings accord with those of the wider AFSUN project working in 11 cities in nine southern African countries [50] and recent research in Accra [51].

Within each of the three household surveys it was clear that although most households did access food through supermarkets, they were far from the main source of food for the sampled households. In Kitwe and Kisumu, 53\% and 55\% of sampled households, respectively, got less than a quarter of food purchased from supermarkets [43,52] (Table 2). On a day-to-day basis, households sourced food from the ubiquitous local neighborhood street traders, house shops, and markets, and central city street traders and markets. Recent work in Tamale, Takoradi, and Accra in Ghana found similar purchasing patterns [53], as did earlier work in three small towns in Kenya [7]. Traders in all three case study cities identified proximity to customers as a key determinant of locational choice and were deeply embedded, with many offering credit to known consumers [32-34].

Table 2. Proportion of food purchased bought at supermarkets. Note: The Kitwe survey was conducted in two low-income neighborhoods. The Kisumu survey was a city-wide survey.

\begin{tabular}{ccccccc}
\hline & Less than $\mathbf{1 0} \%$ & $\mathbf{1 1 - 2 5 \%}$ & $\mathbf{2 6 - 5 0 \%}$ & $\mathbf{5 1 - 7 5 \%}$ & $\mathbf{7 6} \%+$ & Don't Know/Refused to Answer \\
\hline Kitwe & $39 \%$ & $14 \%$ & $7 \%$ & $2 \%$ & $1 \%$ & $37 \%$ \\
\hline Kisumu & $29 \%$ & $26 \%$ & $19 \%$ & $8 \%$ & $3 \%$ & $14 \%$ \\
\hline
\end{tabular}

In these, and in other cities such as Windhoek [54] and Nairobi [55], supermarkets are predominantly located in central city locations and are more typically present in higher-income 
residential areas [48,55]. Research in Cape Town found rapid expansion in the number of supermarkets, with a 2.6-fold increase in the number of supermarkets in the city from 1994 to 2012. This expansion was characterized by two key trends, namely expansion into lower-income areas of the city, and the concentration in existing middle- and high-income areas, in the form of smaller standalone convenience outlets [20]. The outlets opening in lower-income areas were often more limited store formats, lesser a smaller variety of foods than those in wealthier areas [48].

While the findings from each individual research component largely corroborate findings from other studies, with exception of Blekking et al.'s [56] recent work in Lusaka, which thus far has focused on governance issues emanating from their findings, these other studies have focused either on the food system dynamics or on food security. The AFSUN and CUP findings across the three research components allow for critical reflection on the dialectical relationship between food security and the food system, and therefore for critical reflection on policy approaches to alleviating food insecurity through food system interventions, as discussed below.

\section{What the Food Desert Policy Fix Misses}

There are three assumptions at the center of the supermarket as the solution to food insecurity policy discourse. These are: Supermarkets provide better access to healthier food; low income areas have poor access to healthy food; and food security can be reduced to economic and physical accessibility in narrow terms. This section of the paper addresses each of these in turn.

Assumption 1: Supermarkets improve access to healthy food.

Recent work published by Demmler et al. [57] working in urban Kenya found that consumers shopping in supermarkets were not accessing healthier food or better diets. Instead, shopping in supermarkets was found to contribute to higher consumption of processed and highly processed foods and lower consumption of unprocessed foods. This is supported by the work in Cape Town that indicates that the supermarkets entering lower income areas are more likely to be the "budget" lines of major supermarket chains, which sell a much more limited variety of fresh produce [48].

The failure of supermarkets to provide access to healthy foods was clear from field observations in Cape Town, Kisumu, and Kitwe. In all cities, fresh produce traders are regularly located directly outside of the supermarkets. These traders are often selling produce cheaper than the relatively limited stock available within the supermarkets.

Household surveys in Cape Town, Kisumu, and Kitwe confirmed that households do not typically use supermarkets for fresh produce purchases. They more typically use supermarkets infrequently and predominantly use them for non-perishables. They may also be preferred for luxury items like fresh fish, rather than the cheaper dried or smoked fish. Within the Kisumu and Kitwe household surveys, participants were asked to identify where they sourced five foods considered key to the urban diet in those cities. In Kitwe just 15 out of the $882(1.7 \%)$ households surveyed said they bought tomatoes from supermarkets, but 119 (13.5\%) said they normally bought maize meal from supermarkets. In Kisumu 51 out of 841 households (6.1\%) indicated that they normally bought green vegetables from supermarkets, but 299 of 841 (35.6\%) normally bought maize meal from supermarkets. Interestingly, in Kisumu just 12 households $(1.4 \%)$ indicated that they normally bought fish from supermarkets. This extremely low proportion reflects the importance of traditional food purchasing patterns and desire for kinds of products that are not readily available in supermarkets, such as small, dried fish or smoked, whole fish.

In Kisumu households who reported using supermarkets frequently were asked why they did so. Key reasons were variety of foods $(99 \%)$, quality $(83 \%)$, bulk purchasing $(77 \%)$, and lower prices $(50 \%)$. O'Neill [58] (p. 266), also working in Kenya, argues that further reasons for supermarket use include the sales strategies used by stores to attract customers, including flyers, loyalty programs, and sales as well as some stores providing a "lifestyle" experience by selling other household and clothing items as well as food, thereby appealing to a cosmopolitan aspiration. Households who reported not 
shopping at supermarkets frequently were asked why they did not use them. Here, key reasons were lack of provision of credit (69\%) and the high costs of supermarkets $(64 \%)$. The conflicting data on price is interesting. It suggests that for those who can afford to buy in bulk and buy "luxury" products, supermarkets make economic sense, but for those depending on staples and buying in smaller units, the informal sector meets their economic needs more effectively. Within the Cape Town food security survey, it was found that food secure households were more likely to purchase food regularly from supermarkets than food insecure households, despite having similar physical access to the stores. Physical access to supermarkets does not necessarily increase a household's ability to purchase food from these stores.

It therefore appears as if the assumption that supermarkets provide good access to healthy food for an urban population is flawed in its assumptions of what the stores themselves provide and how consumers choose to use them. Supermarkets are not providing better access to healthy food, but instead have been implicated in making more highly processed foods more available $[7,57]$. Therefore, supermarkets may be viewed as accelerating the nutrition transition, rather than addressing food insecurity.

Assumption 2: Low-income areas and their residents have poor access to healthy foods.

The second assumption underlying the promotion of supermarkets is that low-income areas and their residents have poor access to healthy food. However, the research conducted in Cape Town, Kisumu, and Kitwe all demonstrated in both low-income neighborhoods and the central city areas in which many residents of low-income areas work have very good access to fresh produce through informal vendors.

In the Cape Town food mapping work, $19 \%$ of traders in the two sampled wards were fruit and vegetable vendors. Further, the spaza stores (small informal general dealers), which accounted for $39 \%$ of the sampled retailers also stocked limited fresh produce. In Kisumu, of the 2185 recorded vendors, $26 \%$ reported selling vegetable, $30 \%$ fruit, and $11 \%$ roots and tubers. In Kitwe, of the 705 recorded vendors, $31 \%$ sold vegetables, $6 \%$ fruit, and $9 \%$ roots and tubers. In addition to making these foods available, these vendors sell in unit sizes and qualities that the urban poor can access. Produce from these vendors is often cheaper than that of the supermarkets, as they tend to buy direct from wholesale markets, and therefore have shorter supply chains and have fewer costs, such as transportation and cold storage, which increase the price of produce. Furthermore, due to their necessary embeddedness in their location, they often offer food on credit. In the Cape Town sample, $58 \%$ of vendors indicated that they would offer credit. In Kisumu, $48 \%$ offered credit to customers. In Kitwe the proportion was lower at $31 \%$. Although interest was not generally charged, credit was only made available to known customers who were likely to repay.

There is not a shortage of fresh produce available to the urban poor. Physical access to healthy food is not the fundamental food security challenge. Traders provide relatively affordable access to fresh produce and structure their business models to meet consumer needs as best as possible, given their limited margins.

However, as will be discussed in the following section, issues of food utilization through limited cooking resources and storage capacity mean that access to fresh produce alone is not sufficient to ensure consumption of these products. In the sampled cities, relatively healthy prepared foods are also made available through the informal sector. In Kisumu dried porridge mix is commonly sold, which can be quickly reconstituted. In Cape Town, prepared meal vendors of often locate near transport interchanges to sell relatively healthy meals to consumers after long commutes.

Contrary to the vision of the food system invoked by a city-scale food retail mapping focusing on supermarkets to illustrate food deserts, low-income areas are not food deserts in the conventional sense of limited of access to healthy foods. However, there are important questions of physical food access that need to be addressed. 
The first is that of the relative balance of healthy and less healthy foods. While some street vendors are selling healthy cooked meals, a number of street foods are significantly less healthy. Vetkoek or Mandazi (savory doughnuts) are widely sold street foods. And while spaza stores do sell some fresh produce, they generally sell sweets, sodas, potato chips, and other highly processed foods in greater quantities. The high presence of unhealthy traditional street foods and modern highly processed foods has also been noted in research in Ghana [59] and across the SADC region [60] and calls a wider interrogation of trade and agricultural policy. This mixed-food environment with a high presence of less healthy foods has provoked some researchers to discuss the food swamp rather than the food desert [61].

Second, there are important questions about the health and safety of foods sold by informal sector retailers. Across Africa, one of the main ways that urban governments have engaged with the food system has been through repressive health and safety regulation. This is in part the result of colonial governance structures that used public health regulations as a means to entrench urban racial segregation as official state policy [17] (p. 86). This framing has led to present day perceptions by the state of informal food retail as inherently dangerous. However, Skinner [62] (p. iii) argues, "Contrary to the claims of many public officials, the results of toxicology tests of street foods show that informal traders can sell food with low bacterial counts, with access to infrastructure being a decisive factor". Work by the IIED (International Institute for Environment and Development) in Nairobi suggest that the interest of increased food safety (and perhaps transition to a better balance of healthy and less healthy foods on sale) could be better achieved through creating an enabling retail environment with adequate water, sanitation, drainage, regular rubbish collection, storage for vendors, better designed markets with waste disposal site, than by repressive regulation [63].

In many cases, the state's antipathy towards the informal sector has led to the informal food retailers, who remain the primary source of healthy food for the urban poor, having precarious livelihoods impacted by exclusionary zoning schemes, forced removals, and lack of integration into neighborhood planning [64,65]. Through these governance actions, the viability of the food system is undermined.

In the context of the discussion about food deserts as it is currently playing out in the African context, it is important to note that the supermarket companies and the developers who are facilitating the expansion of shopping malls in African cities are not neutral agents around whom these clearance and regulations take place. They have been active agents in advocating for street clearances $[3,20]$.

Assumption 3: Food insecurity in urban areas is simply about economic (and physical) access.

The final assumption is that food insecurity in urban areas is simply about access-economic and physical. This is evidenced in long-term agricultural policy to control maize prices as the central urban food security strategy in many Africa countries. Physical and economic access are necessary, but not sufficient determinants of food security. There is a need to better appreciate how households choose to use limited household economic resources. Food is expenditure is often one of the few discretionary expenditures for poor households. These households often sacrifice economic access to food in order to meet other urban costs of living, such as the cost of transportation, rent, or water [66]. During periods of economic stress, households decrease expenditure on food to meet other household needs and preserve household assets. Research conducted in Manenberg, Cape Town found that income stability rather than amount of income alone was an important determinant of food security. Households with fixed, guaranteed incomes were found to be more food secure than households with equal, or even greater, inconsistent income, as they were able to plan food purchase and preparation better [67].

It is important that food security policy in cities considers the multidimensionality of poverty and how these shape food security outcomes. This requires expanding the framing of food security beyond simple physical and economic access. It demands consideration of the third pillar of food 
security, utilization. According to the FAO, food utilization considers the ability of individuals and households to utilize food through "adequate diet, clean water, sanitation and health care to reach a state of nutritional well-being where all physiological needs are met" [11]. In the Kisumu and Kitwe studies, the Lived Poverty Index was used in which households were asked how often they had gone without access to food, fuel for cooking that food, water, energy, medical treatment, and income [68]. In both cities, households reported significant challenges of access to these (Table 3). The multiple deprivations experienced fundamentally shape households' abilities to ensure food security and dietary quality. Inadequate access to energy to cook shapes food choice, as does access to water to clean and cook foods safely [44].

Table 3. "Over the past year have you or your household ever gone without ... " Note: The Kitwe survey was conducted in two low-income neighborhoods. The Kisumu survey was a city-wide survey.

\begin{tabular}{cccccc}
\hline & Enough Food to Eat & A Cash Income & Water for Home Use & Fuel for Cooking & $\begin{array}{c}\text { Medicine or } \\
\text { Medical Treatment }\end{array}$ \\
\hline Kitwe & $80 \%$ & $88 \%$ & $61 \%$ & $72 \%$ & $62 \%$ \\
\hline Kisumu & $53 \%$ & $65 \%$ & $57 \%$ & $50 \%$ & $50 \%$ \\
\hline
\end{tabular}

The informal components of urban food systems in African cities are responsive to these utilization challenges. In order to address limited household storage and refrigeration, traders bulk break and sell food in small quantities. In recognition of the high cost of energy, street traders sell pre-cooked foods for urban consumers unable to afford to buy raw materials and cooking fuel [69]. Traders respond to the time poverty of the urban poor by locating close to transport interchanges and selling prepared foods [45]. In Cape Town, Kisumu, and Kitwe traders reported operating long hours to meet commuter needs [45].

However, it is important to note these traders are hampered by the same infrastructure deficiencies impacting household utilization. They also commonly lack storage and refrigeration, meaning that they buy in relatively small units to ensure regular throughput of products and therefore food safety [46]. Similarly, traders are also impacted by the high cost of energy, and a number of them use unsafe energy sources to operate [70].

One of the concerns about the increasing presence of supermarkets in African cities is that they are crowding out smaller retailers and informal traders [20]. The concern is that this refining of the market may actually reduce food security. Poor urban households enhance the stability of their food access by accessing food from a range of sources. These different sources respond to supply chain changes differently and prices often vary considerably across different retailers and retail types. In a diverse retail environment, households have greater capacity to find the most affordable prices [71].

This paper argues that it is essential to shift national and global food security policy from its partial interpretation of food security as only encompassing the availability and accessibility pillars. The articulation of economic access needs be extended from its simplistic income and expenditure modeling, to appreciate the role income stability and the economic rationalities of the food insecure. It is further essential to better appreciate how access and utilization interact in the urban context to enhance or hinder food security. The capacity, and infrastructural limitations on adaptive capacity, of small-scale retailers to respond to the food security needs of the urban poor requires that policy-makers and planners adopt an approach to food security that is based on an understanding of the food system that feeds the urban poor and design interventions that support rather than inhibit food security.

\section{Conclusions}

The concept of the food desert is a useful way to raise debate about the structural inequalities in the food system. This is an important addition to policy and academic discussions on food security in the African context, which have often focused either at the household scale or at the national scale, with little consideration of the complex, interrelated determinants of food insecurity. The food desert 
concept also demands that research and policy-makers interrogate the root causes of these determinants, thus raising issues of equity and justice that have often been neglected in African food policy, which is driven more by a poverty-focused development discourse. The application of the food desert concept highlights how food system inequalities overlay with other forms of inequality, such as income poverty, transport poverty, and a lack of basic infrastructure. It is therefore useful in the African context for shifting scales of thinking about food security from the household scale and providing impetus for more structural sets of responses.

However, methodological approaches that generate food desert maps need to be approached with caution. Firstly, the approach may continue to privilege issues of access over a richer understanding of how access and utilization interact. Secondly, maps are powerful and evocative visual references that create particular understandings of issues [72]. The food desert maps that are commonly produced use supermarkets and their absence as a proxy indicator for food access limitations. In order to illustrate the city-wide structural inequality, they generally focus at the city scale. Mapping at this scale necessitates extremely simplistic representations of food retail. The density and diversity of food retail in each neighborhood in the city is inevitably omitted, therefore making the areas without supermarkets appear as food deserts, which invites the framing of the supermarket as the solution to food access problems. This paper suggests that food environment mapping work should be conducted at more than one spatial scale in order to better understand physical access to healthy foods in our cities.

While this paper asserts that the food desert concept has value as a mechanism to shift food security analysis and direct food security programming in cities beyond the household and individual scales, and to increase dialogue about issues of structural inequality, it urges caution. There is a real danger that the operationalization of the food desert concept by researchers will facilitate policy-makers and private sector actors to press forward with a food desert, supermarkets-as-pathway-to-food-security policy discourse and not acknowledge the vital role that informal food retail plays in the food security of African cities. The emergence of the food desert as a policy articulation needs to be understood in terms of the transposition of a problematic policy framing from the United States on pre-existing entrenched narratives about the value of formalization within urban policy [20], powerful industry voices influencing policy positions [2], and the long-term historical framings of food security as being delivered by large scale, economically efficient formal systems [25], at odds with the spatial logic of African cities [21].

In conclusion, there is a need to exercise caution when translating to the concept of the food desert to the African context. The food desert as a policy narrative should be rejected as it is ill-informed by the lived experiences of food insecurity in African cities and may promote policy interventions that erode rather than enhance the capacity of the food system and community agency to meet the food security needs of African urbanites.

Funding: The Consuming Urban Poverty project (Grant Number ES/L008610/1) is funded by the support of the Economic and Social Research Council (UK) and the UK Department for International Development is gratefully acknowledged. The AFSUN project was funded by Canadian International Development Agency (CIDA). Thanks also to the Hungry Cities Partnership funded by the Social Sciences and Humanities Research Council (SSHRC) and the International Development Research Centre (IDRC) under the International Partnerships for Sustainable Societies (IPaSS) Program.

Conflicts of Interest: The author declares no conflict of interest

\section{References}

1. Government of Kenya. Kenya Vision 2030: The Popular Version, Government of Kenya; Government of Kenya: Nairobi, Kenya, 2007.

2. Das Nair, R. The internationalisation of supermarkets and the nature of competitive rivalry in retailing in southern Africa. Dev. S. Afr. 2018, 35, 315-333. [CrossRef]

3. Battersby, J.; Muwowo, F. Planning and governance of food systems in Kitwe, Zambia: A case study of food retail space. In Urban Food Systems Governance and Poverty in African Cities; Battersby, J., Watson, V., Eds.; Routledge: London, UK, 2019; pp. 128-140. ISBN 9781138726758. 
4. Reardon, T.; Hopkins, R. The Supermarket Revolution in Developing Countries: Policies to Address Emerging Tensions Among Supermarkets, Suppliers and Traditional Retailers. Eur. J. Dev. Res. 2006, 18, 522-545. [CrossRef]

5. City of Cape Town. In Resilient Cape Town: Preliminary Resilience Assessment, City of Cape Town, Cape Town; 2018. Available online: https:/ / resource.capetown.gov.za/documentcentre/Documents/City\%20research\% 20reports\%20and\%20review/CCT\%20PreliminaryResilienceAssessment.pdf (accessed on 12 January 2019).

6. Agyemin-Boateng, Y.; Benson-Armer, R.; Russo, B. Winning in Africa's Consumer Market, July 2015. Available online: https:/ / www.mckinsey.com/industries/consumer-packaged-goods/our-insights/win ning-in-africas-consumer-market (accessed on 12 January 2019).

7. Rischke, R.; Kimenju, C.; Qaim, S.; Matin, S.M. Supermarkets and the Nutrition Transition in Kenya, 2014. Global Food Discussion Papers No. 29. Research Training Group (RTG) 1666, Gottingen. Available online: http:/ / hdl.handle.net/10419/97019 (accessed on 12 January 2019).

8. Mason, N.M.; Jayne, T.S. Staple Food Consumption Patterns in Urban Zambia: Results from the 2007/2008 Urban Consumption Survey, 2009. Food Security Research Project Working Paper No. 42, Lusaka, Zambia. Available online: http:/ / www.aec.msu.edu/agecon/fs2/zambia/index.htm (accessed on 12 January 2019).

9. Thow, A.M.; Viljoen, A.; Schoenfeldt, H.; deKock, R.; duRand, G.; Gericke, G.; Negin, J. Policy for the complex burden of malnutrition in Africa: A research agenda to bring consumers and supply chains together. Public Health Nutr. 2016, 20, 1135-1139. [CrossRef] [PubMed]

10. Maxwell, S. Food security: A post-modern perspective. Food Policy 1996, 21, 155-170. [CrossRef]

11. FAO. Food Security. Policy Brief June 2006, Issue 2. 2006. Available online: http:/ / www.fao.org/fileadmin /templates/faoitaly/documents/pdf/pdf_Food_Security_Cocept_Note.pdf (accessed on 12 January 2019).

12. Crush, J.; Riley, L. Urban food security, rural bias and the global development agenda. Hungry Cities Discussion Paper No. 11. Hungry Cities Partnership, Balsillie School of International Affairs, Waterloo, Canada. Available online: http:/ /hungrycities.net/wp-content/uploads/2017/09/HCP11.pdf (accessed on 12 January 2019).

13. Tefft, J.; Janasova, M.; Adjao, R.; Morgan, A. Food Systems for an Urbanising world. World Bank and Food and Agriculture Organization, 2017. Available online: http:/ / documents.worldbank.org/curated/en/45496 1511210702794 / pdf/Food-Systems-for-an-Urbanizing-World.pdf (accessed on 12 January 2019).

14. Crush, J.; Frayne, B. Urban food insecurity and the new international food security agenda. Dev. S. Afr. 2011, 28, 527-544. [CrossRef]

15. Schulz, T.W. On economics and politics of agriculture. Bull. Am. Acad. Arts Sci. 1978, 32, 10-31.

16. Maxwell, D. The political economy of urban food security in sub-Saharan Africa. World Dev. 1999, 27, 1939-1953. [CrossRef]

17. Duminy, J. Historical urban food governance in Africa: The case of Kenya, c. 1900-1950. In Urban Food Systems Governance and Poverty in African Cities; Battersby, J., Watson, V., Eds.; Routledge: London, UK, 2019; pp. 83-93. ISBN 9781138726758.

18. McMichael, P. A food regime analysis of the 'world food crisis'. Agric. Hum. Values 2009, 26, $281-295$. [CrossRef]

19. UN-Habitat. New Urban Agenda; United Nations: Quito, Ecuador, 2016; Available online: http:/ /habitat3.org /wp-content/uploads/NUA-English.pdf (accessed on 12 January 2019).

20. Battersby, J. Food system transformation in the absence of food system planning: The case of supermarket and shopping mall retail expansion in Cape Town, South Africa. Built Environ. 2017, 43, 417-430. [CrossRef]

21. Nandonde, F.A.; Kuada, J. Modern food retailing buying behaviour in Africa: The case of Tanzania. Br. Food J. 2016, 118, 1163-1178. [CrossRef]

22. Battersby, J. Beyond the food desert: Finding ways to speak about urban food security in South Africa. Geografiska Annaler Ser. B Hum. Geogr. 2012, 94, 141-159. [CrossRef]

23. Cummins, S.; Macintyre, S. "Food deserts"-Evidence and assumption in health policy making. BMJ 2002, 325, 436. [CrossRef] [PubMed]

24. McClintock, N. From Industrial Garden to Food Desert: Demarcated Devaluation in the Flatlands of Oakland, California. In Cultivating Food Justice: Race, Class, and Sustainability; Alkon, A.H., Agyeman, J., Eds.; MIT Press: Cambridge, MA, USA, 2011; pp. 89-120. ISBN 9780262516327.

25. Shannon, J. Food deserts: Governing obesity in the neoliberal city. Prog. Hum. Geogr. 2014, 38, $248-266$. [CrossRef] 
26. Walker, R.E.; Keane, C.R.; Burke, J.G. Disparities and access to healthy food in the United States: A review of food deserts literature. Health Place 2010, 16, 876-884. [CrossRef]

27. Eisenhauer, E. In poor health: Supermarket redlining and urban nutrition. GeoJournal 2001, 53, $125-133$. [CrossRef]

28. Short, A.; Guthman, J.; Raskin, S. Food deserts, oases, or mirages? Small markets and community food security in the San Francisco Bay Area. J. Plan. Educ. Res. 2007, 26, 352-364. [CrossRef]

29. Raja, S.; Ma, C.; Yadav, P. Beyond food deserts: Measuring and mapping racial disparities in neighborhood food environments. J. Plan. Educ. Res. 2008, 27, 469-482. [CrossRef]

30. USDA. Definition of a Food Desert. Available online: https://www.ers.usda.gov/webdocs/DataFiles/805 91/archived_documentation.pdf?v=0 (accessed on 12 January 2019).

31. Cannuscio, C.C.; Weiss, E.E.; Asch, D.A. The contribution of urban foodways to health disparities. J. Urban Health 2010, 87, 381-393. [CrossRef]

32. Taylor, D.E.; Ard, K.J. Food availability and the food desert frame in Detroit: An overview of the city's food system. Environ. Pract. 2015, 17, 102-133. [CrossRef]

33. Wang, Y.; Holt-Giménez, E.; Shattuck, A. Grabbing the food deserts: Large-scale land acquisitions and the expansion of retail monopolies. Food First Backgr. 2011, 17, 1-4.

34. Anguelovski, I. Healthy food stores, greenlining and food gentrification: Contesting new forms of privilege, displacement and locally unwanted land uses in racially mixed neighborhoods. Int. J. Urban Reg. Res. 2015, 39, 1209-1230. [CrossRef]

35. Block, D.R.; Chávez, N.; Allen, E.; Ramirez, D. Food sovereignty, urban food access, and food activism: Contemplating the connections through examples from Chicago. Agric. Hum. Values 2012, 29, 203-215. [CrossRef]

36. Giacalone, S. Making Food Deserts: The Technopolitics of Mapping Urban Food Access and the Professionalization of Food Justice. Honors Thesis, Department of Anthropology, Tufts University, Medford, MA, USA, 2017. Unpublished work.

37. Larsen, K.; Gilliland, J. A farmers' market in a food desert: Evaluating impacts on the price and availability of healthy food. Health Place 2009, 15, 1158-1162. [CrossRef]

38. Dimitri, C.; Oberholtzer, L.; Zive, M.; Sandolo, C. Enhancing food security of low-income consumers: An investigation of financial incentives for use at farmers markets. Food Policy 2015, 52, 64-70. [CrossRef]

39. Safe Routes to School National Partnership The Wheels on the Bus Go to the Grocery Store, 2017. Available online: https://www.saferoutespartnership.org/sites/default/files/resource_files/wheels_on _the_bus_0.pdf (accessed on 12 January 2019).

40. Ver Ploeg, M.; Rahkovsky, I. Recent Evidence on the Effects of Food Store Access on Food Choice and Diet Quality. 2016. Available online: https://www.ers.usda.gov/amber-waves/2016/may/recent-evidence-on-t he-effects-of-food-store-access-on-food-choice-and-diet-quality/ (accessed on 12 January 2019).

41. Coates, J.; Swindale, A.; Bilinsky, P. Household Food Insecurity Access Scale (HFIAS) for Measurement of Food Access: Indicator Guide (v.3); Food and Nutrition Technical Assistance Project, Academy for Educational Development: Washington, DC, USA, 2007.

42. Battersby, J. The State of Urban Food Security in Cape Town, Urban Food Security Series No. 11, AFSUN: Queen's University, Canada, 2011. Available online: http:/ /www.afsun.org/wp-content/uploads/2017/07 / Afsun11.pdf (accessed on 12 January 2019).

43. Fuseini, I.; Sichone, O. Food poverty in Kitwe, Zambia. In Urban Food Systems Governance and Poverty in African Cities; Battersby, J., Watson, V., Eds.; Routledge: London, UK, 2019; pp. 236-248.

44. Wagah, G.G.; Obange, N.; Ogindo, H. Food poverty in Kisumu, Kenya. In Urban Food Systems Governance and Poverty in African Cities; Battersby, J., Watson, V., Eds.; Routledge: London, UK, 2019; pp. 223-235. ISBN 9781138726758.

45. Battersby, J.; Marshak, M.; Mngqibisi, N. Mapping the invisible: The informal food economy of Cape Town, South Africa. Hungry Cities Partnership Discussion Paper No. 5. 2016. Available online: http:/ / hungrycities.net/publication/hcp-discussion-papers-no-5-mapping-informal-food-economy-ca pe-town-south-africa/ (accessed on 12 January 2019).

46. Fuseini, I.; Battersby, J.; Jain, N. The characteristics of the urban food system in Kitwe, Zambia: A focus on the retail sector. In Urban Food Systems Governance and Poverty in African Cities; Battersby, J., Watson, V., Eds.; Routledge: London, UK, 2019; pp. 195-207. ISBN 9781138726758. 
47. Opiyo, P.; Ogindo, H.O. The characteristics of the urban food system in Kisumu, Kenya. In Urban Food Systems Governance and Poverty in African Cities; Battersby, J., Watson, V., Eds.; Routledge: London, UK, 2019; pp. 182-194. ISBN 9781138726758.

48. Battersby, J.; Peyton, S. The geography of supermarkets in Cape Town: Supermarket expansion and food access. Urban Forum 2014, 25, 153-164. [CrossRef]

49. Crush, J.; Caesar, M.; Haysom, G. The State of Household Food Security in Cape Town, South Africa, Hungry Cities Report No. 12, Hungry Cities Partnership, African Centre for Cities, African Centre for Cities, University of Cape Town, South Africa, and Wilfrid Laurier University/Balsillie School of International Affairs, Waterloo, Canada, 2018. Available online: http://hungrycities.net/wp-content/uploads/2018/09/ HCP12.pdf (accessed on 12 January 2019).

50. Crush, J.S.; Frayne, G.B.; Pendleton, W. The crisis of food insecurity in African cities. J. Hunger Env. Nut. Dev. S. Afr. 2012, 7, 271-292.

51. Tuholske, C.; Andam, K.S.; Blekking, J.; Evans, T.; Caylor, K. Measures and Determinants of Urban Food Security: Evidence from Accra, Ghana; IFPRI Strategy Support Program Working Paper No. 50; IFPRI: Accra, Ghana, 2018.

52. Battersby, J.; Watson, V. Addressing food security in African cities. Nat. Sustain. 2018, 1, 153-155. [CrossRef]

53. Dreschel, P. Food shopping preferences. In Atlas of West African Urban Food Systems: Examples from Ghana and Burkino Faso; Karg, H., Dreschel, P., Eds.; International Water Management Institute (IWMI). CGIAR Research Program on Water, Land and Ecosystems (WLE): Columbo, Sri Lanka, 2018; p. 55. ISBN 978-92-9090-875-3.

54. Nickanor, N.; Kazembe, L.; Crush, J.; Wagner, J. The supermarket revolution in Namibia, AFSUN Working Paper No. 26, African Food Security Urban Network, 2017. Available online: http:/ /www.afsun.org/wp-c ontent/uploads/2017/11/AFSUN26.pdf (accessed on 12 January 2019).

55. Berger, M.; van Helvoirt, B. Ensuring food secure cities-Retail modernization and policy implications in Nairobi, Kenya. Food Policy 2018, 79, 12-22. [CrossRef]

56. Blekking, J.; Tuholske, C.; Evans, T. Adaptive governance and market heterogeneity: An institutional analysis of an urban food system in sub-Saharan Africa. Sustainability 2017, 9, 2191. [CrossRef]

57. Demmler, K.M.; Klasen, S.; Nzuma, J.M.; Qaim, M. Supermarket purchase contributes to nutrition-related non-communicable diseases in urban Kenya. PLOS ONE 2017, 12, e0185148. [CrossRef]

58. O'Neill, K. Big Food without big diets? Food regimes and Kenyan diets. Crit. Public Health 2015, 25, $265-279$.

59. Andam, K.S.; Tschirley, D.; Asante, S.B.; Al-Hassan, R.M.; Diao, X. The transformation of urban food systems in Ghana: Findings from inventories of processed products. Outlook Agric. 2018, 47, 233-243. [CrossRef]

60. Thow, A.M.; Sanders, D.; Drury, E.; Puoane, T.; Chowdhury, S.N.; Tsolekile, L.; Negin, J. Regional trade and the nutrition transition: Opportunities to strengthen NCD prevention policy in the Southern African Development Community. Glob. Health Act. 2015, 8, 28338. [CrossRef]

61. Rose, D.; Bodor, J.N.; Swalm, C.M.; Rice, J.C.; Farley, T.A.; Hutchinson, P.L. Deserts in New Orleans? Illustrations of urban food access and implications for policy. Paper prepared for: University of Michigan National Poverty Center/USDA Economic Research Service Research “Understanding the Economic Concepts and Characteristics of Food Access" February 2009. Available online: https:/ / pdfs.semanticscholar.org/abc8/b418aa0783c8f3b0a0c4 fca8f137ad806e0a.pdf (accessed on 12 January 2019).

62. Skinner, C. Informal Food Retail in Africa: A Review of Evidence, Consuming Urban Poverty Project Working Paper No. 2, African Centre for Cities, University of Cape Town, South Africa, 2016. Available online: https:/ / consumingurbanpoverty.files.wordpress.com/2015/10/cupworkingpaper2-sk inner-informal-retail.pdf (accessed on 12 January 2019).

63. Ahmed, S.; Simiyu, E.; Githiri, G.; Sverdlik, A.; Mbaka, S. Cooking Up a Storm, Community-Led Mapping and Advocacy with Food Vendors in Nairobi's Informal Settlements; IIED Working PaperIIED: London, UK, 2015.

64. Western Cape Informal Traders Coalition; The Somali Association of South Africa; The National Consumer Forum; COSATU Western Cape; PASSOP; The South African Council of Churches; The Scalabrini Foundation; The Black Business Chamber. Press Release: Implementation of New by-Laws Affecting Spaza Shops. 30 April 2013. Available online: http:/ / www.passop.co.za/news/the-implementation-of-new-by-laws-coul d-force-up-to-70-of-spaza-shops-in-cape-town-to-close (accessed on 12 January 2019).

65. Rogerson, C.M. Responding to informality in urban Africa: Street trading in Harare, Zimbabwe. Urban Forum 2016, 27, 229-251. [CrossRef] 
66. PACSA. PACSA 2017 Food Price Barometer: Annual Report; PACSA: Pietermaritzburg, South Africa, 2017.

67. Cooke, K. Urban Food Access: A Study of the Lived Experience of Food Access Within a Low-Income Community in Cape Town. Master's Thesis, Department of Environmental and Geographical Science, University of Cape Town, Cape Town, South Africa, 2012. Unpublished work.

68. Mattes, R. The material and political bases of lived poverty in Africa: Insights from the Afrobarometer. In Barometers of Quality of Life around the Globe; Social Indicators Research Series; Møller, V., Huschka, D., Michalos, A.C., Eds.; Springer: Dordrecht, The Netherlands, 2008; Volume 33, pp. 161-185. ISBN 978-1-4020-8685-4.

69. Kimani-Murage, E.W.; Schofield, L.; Wekesah, F.; Mohamed, S.; Mberu, B.; Ettarh, R.; Egondi, T.; Kyobuntgi, C.; Ezeh, A. Vulnerability to food insecurity in urban slums: Experiences from Nairobi, Kenya. J. Urban Health Bull. N. Y. Acad. Med. 2014, 91, 1098-1113. [CrossRef] [PubMed]

70. Dalvie, M.A.; Africa, A.; Naidoo, S. Relationship between firewood usage and urinary Cr, $\mathrm{Cu}$ and As in informal areas of Cape Town. S. Afr. Med. J. 2014, 104, 61-64. [CrossRef] [PubMed]

71. Battersby, J.; Haysom, G. Linking urban food security, urban food systems, poverty and urbanisation. In Urban Food Systems Governance and Poverty in African Cities; Battersby, J., Watson, V., Eds.; Routledge: London, UK, 2019; pp. 56-67. ISBN 9781138726758.

72. Kwan, M.-P. Feminist Visualization: Re-Envisioning GIS as a Method in Feminist Geographic Research. Ann. Assoc. Am. Geogr. 2002, 92, 645-661. [CrossRef]

(C) 2019 by the author. Licensee MDPI, Basel, Switzerland. This article is an open access article distributed under the terms and conditions of the Creative Commons Attribution (CC BY) license (http://creativecommons.org/licenses/by/4.0/). 